\title{
Introducing Civil Clauses against Expanding Military Research at German Universities? A Descriptive and Ethical Analysis of the Discussion*
}

\author{
Kerstin Schlögl-Flierl/Alexander Merkl
}

\begin{abstract}
Over the last 10 years, students and professors at German universities have intensely discussed the implementation of the controversial Civil Clauses. In light of a well-documented expansion of military research at German state universities, the pros and cons of this political instrument at universities should be discussed within an ethical framework. For the Civil Clause to be viable and to be seen as a means for self-assurance, an 'ethos of epistemic rationality' and a well-defined 'ethos of scientific responsibility' is as much necessary as the consideration of criteria like transparency and the implementation of ethical review committees.
\end{abstract}

Keywords: Civil Clauses, universities, peace and military research, controversy, political instrument of self-assurance Stichwörter: Zivilklausel, Universitäten, Frieden und militärische Forschung, Kontroverse, politisches Instrument der Selbstvergewisserung

\section{Introduction: The Civil Clause - a Current Topic in German Higher Education Policies}

M ilitary use of university research has not only been discussed intensely in German academia, but also in other countries and other venues. General awareness for the challenges concerning this topic has been fostered by the usage of non-Newtonian fluids in sports and the military. Concussions are notably a big problem in American Football as they can lead to chronic traumatic encephalopathy. Researches therefore and already in 2014 improved helmets so that they can protect players better against incoming blows and hits. ${ }^{1}$ They made use of low-cost pouches filled with non-Newtonian fluids that should protect any part of the brain also from the rotational or shearing force of off-center hits on helmets. The researcher came up with the idea while working on improving helmets and body armor for the military, so the research can also be used for this purpose. It has a dual use. The discussion is still up. ${ }^{2}$

This example quite plainly shows the basic reason for why Germany has heavily discussed Civil Clauses. Adding to the concern is the fact that armament research is often one of the main financial sources of universities in countries such as the United States and Britain. Investigations by the Norddeutscher Rundfunk and the Süddeutsche Zeitung revealed in 2013 that German state universities have received more and more money for research projects both from abroad (by the Pentagon) and from the German Ministry of Defense. ${ }^{3}$

In our first chapter, we therefore give an analysis of the current situation and want to show in what way the Civil Clause is

1 See https://www.reuters.com/article/us-usa-football-concussion/ florida-researchers-developing-football-helmets-to-reduce-concussionsidUSBREA071IH20140108 (accessed 2018-03-24).

2 See https://edition.cnn.com/2017/03/27/tech/d3o-orange-gel/index. html (accessed 2018-03-24).

3 See A. Meyer et al., 'Unis forschen immer mehr für die Rüstung', Süddeutsche Zeitung, July 6, 2014, online at http://www.sueddeutsche' de/bildung/im-auftrag-des-verteidigungsministeriums-unis-forschenimmer-mehr-fuer-die-ruestung-1.2033114 (accessed 2017-09-19). See the opponent J. Krause, 'Die Hochschule als entmilitarisierte Zone. Über die Einführung von Zivilklauseln', Forschung und Lehre 21:3 (2014), pp. 192-193. discussed at German universities. In the second chapter, we offer an analysis of this political instrument by comparing different arguments and illustrating controversial debates and topics. In the third chapter, we reflect on the ethical dimensions of this political instrument as a kind of self-assurance of universities, which is most of the times institutionalized in a democratic process. In conclusion, we will give a short summary of our introductory overview.

\section{Situation Analysis: The Civil Clause Movement in Germany}

More recent studies show that the number of Civil Clauses at German universities has surged, especially between 2011 and 2014. At the beginning of the millennium as few as ten Civil Clauses were in place; now there are over sixty. There has also been a significant rise in Civil Clauses in Higher Education Legislation (Landeshochschulgesetzgebung) ${ }^{4}$

Student motivation and action have risen considerably in response to the above-mentioned disclosure of data. The Civil Clause Movement, which resisted military research in Karlsruhe in 2009, had regained strength. Since 2011, an initiative 'Academia for Peace - Say Yes to Civil Clauses' has advocated as a nationwide network for the establishment of Civil Clauses at German universities. With the involvement of students, strike ballots have led to an inclusion of the Civil Clause into university constitutions in many places. Two recent examples are the following: In 2012, the University of Cologne decided not to conduct research on military affairs and armaments research as well as not to cooperate with the war industry. ${ }^{5}$ The MIN 6 -Department of the University of Hamburg approved a Civil Clause in February 2017 which reads as follows: "The

4 See http://www.zivilklausel.de/index.php/zivilklausel-dokumentation (accessed 2017-06-20).

5 See H. Burmester, 'Zivil- und Friedensklauseln in Deutschland: Ein Wachhund ohne Zähne?', Zivilklauseln für Forschung, Lehre und Studium. Hochschulen zum Frieden verpflichtet, edited by T. Nielebock et al. (BadenBaden: Nomos, 2012), pp. 79-111.

$6 \mathrm{MIN}$ is the abbreviation for mathematics, informatics, natural sciences. 
MIN-Department solely wants to make a contribution to peaceful objectives and fulfill merely civil purposes. Its members therefore aim its research (-progress), studies and teaching activities at civil questions and utilizations." ${ }^{7}$

Notwithstanding, the Civil Clause is not an entirely new and only recently applied policy instrument. The University of Bremen enshrined a Civil Clause as early as 1986, which has been repeatedly affirmed (1991/2012), despite recurring challenges. Since 2015, it has also been included in the Bremen Higher Education Act. Furthermore, the University of Konstanz had already established in 1991 that research for military purposes, especially the production of weapons of mass destruction, is not allowed.

\subsection{Queries and Challenges}

At the same time, challenges have surfaced again and again, especially regarding the manner in which Civil Clauses are phrased. This can be shown paradigmatically on the basis of the cooperation between the University of Bremen and the Federal Agency for Human Resource Management of the German Armed Forces in an international integrated degree program for exclusively female information scientists. ${ }^{8}$ This liaison sparked controversies in 2016, raising the question if such cooperation constitutes a violation of the Civil Clause of the Bremen Higher Education Act as well as the University's own Civil Clause. What followed were protests by the General Students' Committee against the cooperation claiming it turned the Civil Clause into a mockery. There was also a letter of inquiry by the German party Die Linke to the Bremen Federal State Government in February 2017.

The Bremen government responded in a rather self-contradictory manner by saying that cooperation 'which pursue military purposes and is not in line with the guiding principles of the German Constitution' is to be prevented. However, ' $\mathrm{t}$ ] he German Armed Forces as a defense army is within the boundaries of the constitutional principles' and operates on the commission to keep the peace - if need be by military means - is always in alignment with the 'principles of our Constitution'. ${ }^{9}$

A further need of discussion can also be found in the phrasing of other Civil Clauses. For example, the Civil Clause at the University of Kassel, initially presented in 2013, states:

Research and development, teaching and studies at the University of Kassel are committed to peaceful aims and they are to fulfil non-military purposes; research connected to the development and optimization of technological systems especially, as well as study and teaching activities are aimed at a civil usage.

Four controversial points need to be addressed in this context: ${ }^{10}$ Firstly, the 'are to'-formulation leaves a considerable leeway

7 Quoted from http://www.das-marburger.de/2017/02/zivilklauseln-fuerdie-universitaeten/ (accessed 2017-06-20).

8 See http://www.deutschlandfunk.de/hochschule-bremen-und-diebundeswehr-kooperation-zum.680.de.html?dram:article_id=363865 (accessed 2018-03-27).

9 See Bremische Bürgerschaft, Antwort des Senats auf die Kleine Anfrage der Fraktion DIE LINKE. Studiengangskooperation mit der Bundeswehr an der Hochschule Bremen, online at http://www.bremische-buergerschaft.de/ dokumente/wp19/land/drucksache/D19L0949.pdf (accessed 2017-09-19).

10 See C. Holzner and J. Firges, 'Forschung, Lehre und Studium zwischen Campus, Industrie und Militär', Kriege im 21. Jahrhundert. Neue Herausforderungen der Friedensbewegung edited by R. Bauer (Anweiler: Sonnenberg, 2015), pp. 95-109, at p. 102. for the use of technologies for military purposes; secondly, a clause on transparency which is meant to buttress the Civil Clause and make known third-party funding university-wide does not come into action; thirdly, no ethical review committee is installed as a controlling implementation agency and lastly, following as a consequence, the Civil Clause is not liable to validation and is, therefore, of mere symbol-political value.

\subsection{Conceptual Distinctions: Civil Clause or Peace Clause/Civil or Peaceful?}

To further clarify these points, it can be mentioned that if the Clause is laid down in the constitution of a university, it has a more binding commitment than in a senatorial decree. It is of ethical relevance whether direct cooperation is explicitly named or if only the general purposes of peace and freedom are stated. For example, a senatorial decree at the University of Göttingen reads: "The University commits itself to peace and justice in the world. The University and the employed researchers strive for peace in the world by means of their research- and teaching activities. In their actions, they are obligated to society and the ethical principles inherent to science."11

That is why the Civil Clause is often also called peace clause, „Friedensklausel“, meaning that the universities have promoted peaceful purposes in lecturing and research (see the University of Tübingen).

This also means that peace clauses are somewhat more abstract than Civil Clauses because an actual definition for peace is hard to come by. ${ }^{12} \mathrm{~A}$ related point of criticism, especially regarding established terminology, now becomes visible: What are non-peaceful purposes and what are peaceful purposes? And how can the aim of peace be achieved in the context of a university? All scientific means can be used for peace and for opposite goals, the so called dual-use. The promotion of peace becomes a nebulous and problematic issue because of the failure to define peace exactly: Is peace, for example, the absence of war or a certain quality of life? The lack of an answer to such questions leads to overly general Civil Clauses that state only that studying, lecturing and research should not intend military, but civil aims. Means and contents should be civil. ${ }^{13}$ Peace is only indirectly promoted as an abstract goal. Concerning the afore-mentioned controversies surrounding the cooperation of the University of Bremen and the Federal Agency of Human Resource Management of German Armed Forces, a legal opinion by the Kassel lawyer Bernd Hoppe dealt directly with the question of what the adjectives 'peaceful' and 'civil' in the Bremen Civil Clause actually are. The report concludes as follows:

The genesis of the [Bremen] Civil Clause shows that the used term 'peaceful' is to be read as 'unmilitary' or 'non-military'. [...] The word 'civil' is used in distinction to 'military'. [...] The term 'peaceful' in the Civil Clauses does not only imply the nuances of peaceable, conciliatory, quiet, still and filled by peace.

11 Göttingen im Juli 2006, Ergänzung der Zivilklausel durch Beschluss des Senats vom 13. Februar 2013 online at https://www.uni-goettingen.de/ de/43883.html (accessed 2017-06-20).

12 See J. Frühbauer, 'Konfliktüberwindung und Kultur des Friedens', Christliche Sozialethik. Ein Lehrbuch, vol. 2, edited by M. HeimbachSteins (Regensburg: Pustet, 2005) pp. 163-192, at pp. 181-186. 13 See Burmester, 'Zivil- und Friedensklauseln in Deutschland', p. 83. 
It rather turns against all military implications. Therefore, each and any kind of cooperation of the University of Bremen and the Armed Forces is impossible. ${ }^{14}$

\section{Civil Clause: What is it exactly? - Arguments and Controversies}

But why is it necessary - for all the difficulties and controversies to have a Civil Clause at all? In the title of this contribution, the expansion of military research at German state universities is mentioned. This controversial topic ${ }^{15}$ includes the question of how much is really financed by the Ministry of Defense or the war industry. Data about costs are not readily attainable. To get information about this issue, political parties in Germany, like Die Linke or Die Grünen, have demanded more transparency. This demand has not been met at all yet. It must be noted, however, that in times of expanding acquisition of external funds/thirdparty funds and, furthermore, a changing notion of security, questions of civil uses of scientific results should be discussed more openly and carefully. Some general and paradigmatic guiding question for these (possibly) arising debates could be: Where are university funds coming from and with what obligation?

Beside these general questions, it should be said that all people and departments involved at university are impacted by the Civil Clause: from political science to medicine, from German literature to physics. The Civil Clause can mean that the staff of a university is not allowed to contribute to special issues in national or international research, or to acquire external funds/third-party funds in certain fields, or to have professional connections with military industry or practitioners. For this reason, the field 'policies of security' is a difficult area of investigation at state universities.

Put in a nutshell: The Civil Clause is aimed at recognizing military research and its possible dual use. It is a voluntary agreement to engage exclusively in civil research and teaching at universities. It is further intended to raise awareness about these sensitive issues.

Opponents, therefore, criticize that an open-minded discussion is aggravated or thwarted this way. Especially a public and universityinternal dialogue and cooperation, e.g. with (members of) the German Armed Forces is often challenged by a narrow interpretation of the Civil Clause. Research is only transferred from university to industry. The opinions are diverging, as we can see.

\subsection{Arguments by Advocates and Opponents}

Despite these fundamentally comprehensible intentions, the entrenchment of a Civil Clause at German universities is treated as a controversial subject. Advocates plead for Article 26 of the German Constitution as well as for the general notion and aim to pursue peace, which is $\mathrm{f}$. ex. expressed in the preamble of

14 B. Hoppe, Rechtsgutachten zur Frage, ob die beabsichtige Kooperation zwischen der Hochschule Bremen und dem Bundesamt für das Personalwesen gegen die Zivilklausel des Bremischen Hochschulgesetzes und der Hochschule Bremen verstößt, pp. 3-4, online at www.zivilklausel.de (accessed 2017-06-20).

15 See Krause, 'Die Hochschule als entmilitarisierte Zone', pp. 192-193; R. Bayer, 'Militärforschung wächst - Widerstand auch', biwifo Report 01/2013, p. 3, online at https://biwifo.verdi.de/++file++531c4f53aa69 8e35de000323/download/biwifo2013-01.pdf (accessed 2017-09-19). the constitution (Friedensfinalität), while opponents insist on academic freedom (Art. 5 §3). The arguments brought up by both parties will be discussed briefly.

According to the advocates, there is no contradiction between the Civil Clause and academic freedom. They put the main emphasis on the Friedensfinalität as laid down by the German Constitution and consider it as more important. They stress the necessity of debates which go beyond university discussions about the Civil Clause and promote societal awareness. They position themselves against external research control, which results from a dependence on profitable third-party-funding. They demand an improvement of the financial means of universities. Furthermore, they point out that universities should be able to choose their academic orientation more freely and that it is within its employees' discretion to utilize benefits of the university. The following statement by the Rektor of the RWTH Aachen, Ernst Schmachtenberg, can be cited as an exemplary conclusion corresponding to this positioning: "The German armaments research has caused a lot of damage. I do not consider it a viable method for an open-minded university in Germany. If armaments research is endorsed politically, it should be conducted by scientific institutes created exclusively for that purpose." 16

In contrast, the opponents of the Civil Clause (see for example the Resolution of the 64th DHV-Day, the association of German scientists, in March 2014) consider the implementation of a Civil Clause an inappropriate means to bring peace. The individual right of each scientist to academic freedom and lecturing is stressed and it is argued that scientists should be able to retain their basic convictions ("Gesinnungsvorbehalt") when a Civil Clause is laid down. There can be no obligation for pacifism. Opponents such as the scientist Joachim Krause say: "I am against the civil clauses, because it would hinder my work here in Kiel. I cooperate with the army in different fields. 2011 and 2013, I did a project in cooperation with the Ministry of Defense by learning from the deployment in Afghanistan for future deployments in the purpose of consolidating peace."17

Furthermore, opponents argue that the German perspective is disproportionately dominated by possible risks, which leaves chances untaken and even thwarts innovation. The internet as well as the navigation device GPS are no mere byproducts of military research. Moreover, if military research was not possible at universities, grants would be given to private research institutes and not to universities. Finally, the disqualification of research results and its military use - especially in the field of foundational research is hardly possible and diametrically contradicts the openness and liberty of research and science. The misuse of militarily usable research results can be met by criminal law, the law for the control of military weapons and by the foreign trade legislation as effective legal instruments. As stated by the Deutscher Hochschulverband: "Therefore, no encroachment on academic freedom is necessary."18

16 Quoted from: Ch. Hubig, 'Zivilklauseln an Universitäten', Forschung und Lehre 10 (2012), online at www.forschung-und-lehre.de/ wordpress/?p=11813 (accessed 2017-06-20).

17 See https://www.ispk.uni-kiel.de/de/publikationen/meinung-undkommentar-1/uploads-kommentare-interviews/stellungnahme-profdr-joachim-krause-zur-zivilklausel.pdf (accessed 2016-07-20).

18 Deutscher Hochschulverband, Nein zur Zivilklausel. Resolution des 64. DHV Tages, p. 2, online at https://www.hochschulverband.de/fileadmin/redaktion/ download/pdf/resolutionen/Nein-zur-Zivilklausel.pdf (accessed 2017-02-17). 
The DHV refers to the fact that there are other mechanisms to reach the same goal see above. There is no need to limit the liberty of research for each scientist by Civil Clauses.

\subsection{Civil Clauses: Constitutional or Anti-Constitutional?}

The opinions concerning the constitutionality of the Civil Clause at German universities are similarly diverse and disparate. The Kassel lawyer Bernd Hoppe and the Frankfurt law professor Erhard Denninger ${ }^{19}$ plead in favor of the constitutionality of the Civil Clause. In their expert reports, they claim that the Friedensfinalität as determined by the German Constitution outweighs other factors. As the German Constitution contains peacekeeping as a mission statement, an infringement of academic freedom by the Civil Clause can be justified as the legally protected right to peace is safeguarded. ${ }^{20}$

Differing from that opinion, the law professor Friedhelm Hufen from Mainz talks about "grave constitutional queries" 21 and concludes:

Content and cause of research endeavors are irrelevant to the fundamental validity of academic freedom. The German Constitution protects foundational research as well as applied and practical research, pure and commissioned research, internal as well as external, airy-fairy as well as marquee research, typical and atypical forms of teaching. ${ }^{22}$

Delegitimizing the recourse to Friedensfinalität in Article 26 and the preamble of the German Constitution, Hufen argues that this article only applies to wars of aggression and other acts of war opposing international law. He discards general bans on 'military research' or militarily utilizable research and abstract Civil Clauses as well as basic restraints to commissioned research by the military sector and similar constraints. ${ }^{23}$ Specific interventions against academic freedom like exerting pressure, threat of punishment, and the imposition of sanctions or obligatory consulting require reasoned justification in order not to violate the German Constitution. The interests of academic freedom have to be weighed against risks for other legally protected rights (e.g. research conducted on people who are incapable to give consent, animal testing, etc.).

As shown, the German Constitution warrants academic freedom in Art. 5 clause 3. The juridical question arises whether this guarantee can be reduced by interests of civil factors. The fundamental problem behind this is: Is academic freedom subordinate or superordinate to the constitutionally anchored primacy of peace? A thorough process of assessment and analysis is still necessary to find a profound answer. Analogous to the issue of armed intervention, an orientation by means of international law and ethical legitimacy is possible also in the case of the Civil Clause ${ }^{24}$ - although ethical considerations

19 See https://www.boeckler.de/pdf/mbf_gutachten_denninger_2009.pdf (accessed 2018-03-23)

20 See Hoppe, Rechtsgutachten.

21 F. Hufen, 'Wissenschaft in Freiheit und Verantwortung. Braucht Forschung Aufpasser?', Forschung und Lehre 24:2 (2017), pp. 118-120.

22 Hufen, 'Wissenschaft', p. 118.

23 See Hufen, 'Wissenschaft', p. 120.

24 See E. Denninger, 'Freiheit der Wissenschaft und die Friedensfinalität der Verfassung', Erzählungen vom Konstitutionalismus, edited by $\mathrm{H}$. Lindemann et. al. (Baden-Baden: Nomos, 2012), pp. 206-220. certainly cannot justify encroachments on constitutional guarantees. So far, however, this issue has not been resolved.

\subsection{The Problem of Dual Use}

These publicly and legally discussed arguments in the preceding parts show how difficult it is to declare the final purpose of research particularly in times of the dual use of results which has already been mentioned and now needs some more clarification.

In general, 'Dual Use' constitutes a gray area. It is a debatable point whether Civil Clauses constitute an appropriate instrument for clarification. In many cases, it is difficult if not merely impossible to discern if the use of research results is aimed at purely civil or military aims. Furthermore, the dual use within military objectives, i.e. for defensive or aggressive purposes, has to be pointed out. While it makes sense to picture the relationship of civil and military research as a continuum as opposed to make a sharp distinction, four guiding questions ${ }^{25}$ can function as basic landmarks to distinguish military from civil purposes: Who provides funds for research? Who determines the research topic? Who controls the results? Who decides on the publication?

Additionally, it has to be remarked, as Friedhelm Hufen does, that users of research results and the researchers themselves have to be put into different categories. As a rule prohibitions of use should be aimed at users primarily and only at the researcher, if he is the user by himself or if he has a special responsibility for the usage, for example in the context of contract research. Misuse also has to be prosecuted, but in general not with the researcher - only again under certain conditions, f. ex. because of negligence - but with the mis-user. This follows the (ethical) principle: abusus non tollit usum - the misuse of an object does not negate its (proper) usage. ${ }^{26}$ But there are more ethical dimensions in discussing the Civil Clause, as we will see below.

\section{Analysis of the Ethical Dimensions of Civil Clauses as a Political Instrument of Self-Assurance}

The analysis of the ethical relevance of Civil Clauses as an instrument of university policies is the third step of the paper, although several important aspects have been mentioned beforehand; i.e. questions concerning university, society, and state. From an ethical perspective, it is more a question of professional ethics, the ethos of scientists, and less a constitutional one, if at all. ${ }^{27}$

\subsection{A Matter of Ethos}

For the Civil Clause to be viable, an 'ethos of epistemic rationality' as well as a well-defined ethos of scientific responsibility is necessary. The 'ethos of research/epistemic rationality' is basically characterized by these four following principles: the universality of validity

25 See Holzner and Firges, 'Forschung', pp. 104

26 See Hufen, 'Wissenschaft', p. 120.

27 K. Herzmann, 'Friedlichkeitsforderungen' an die universitäre Forschung als rechtliche Sackgasse? Zur Vereinbarkeit von Zivilklauseln mit der Wissenschaftsfreiheit', Wissenschaftsrecht 44:4 (2011), pp. 375-392, at p. 385 
claims (1), systematic/methodical doubt (2), disinterestedness of research (3), and research results as common property (4). Internal responsibility is monitored by the scientific community. Knowledge as a common property is a pivotal value in high-quality research and is secured by the imperative of publicness. ${ }^{28}$ These values play an important role in the discussions on the Civil Clauses and require among other things the dissemination of acquired results: "The inadmissibility of a precluding generation of knowledge and a selective disclosure of information cannot only be concluded from a demand for methodical doubt but also from a posit of scientific knowledge as common property." 29 Research is to be conducted as accessibly and publicly as possible.

From an ethical perspective, the often-lacking transparency of third party funding needs to be met by uniform and nationwide standards and the Civil Clause must be supplemented by a transparency clause, as in the case of the Bremen Higher Education Act ( $\$ 74$ paragraph 6). Bremen University commits itself - in addition to the Civil Clause ( $(7 \mathrm{~b})$ - to making available all research projects by means of a publicly accessible database, which includes the titles, contents, objectives, duration as well as the identity of third-party-donors and the sum provided by them. That is important for several reasons: High standards of research can be secured by this kind of publicness and transparency. At the same time, the societal entitlement to know about the consequences of the conducted research can be met. At last transparency is a fundamental condition and a considerable criterion for avoiding misuse and for exercising control.

Thomas Nielebock, therefore, calls for a complementary widening of the unproblematic 'ethos of epistemic rationality' by an 'ethos of scientific responsibility' in contemporary academia: responsibility has to be taken for the direct and indirect consequences of research results. ${ }^{30}$ Debates on the Civil Clause, however, show that the two types of 'ethos' pose conflicting interests; furthermore, there is no consent on an 'ethos of scientific responsibility' within the scientific community. To take responsibility for one's own research results is argued against, as no single scholar can manage the task by him- or herself; cooperative and institutional support is necessary.

\subsection{In Lieu of Mere Symbolic Politics - Facilitating Implementation Processes}

These deliberations give rise to yet further difficult questions like these more practical ones: how to work with the Civil Clause in the university context? Is there a need for an institutionalized mechanism evaluating the practical impact of these norms, if the Civil Clause is laid down in the constitution of a university? If a Civil Clause is to be effective, on which level should it be discussed, at which scale, and with which measures will it be promoted at a certain university?

28 See R. Ammicht Quinn and M. Nagenborg, 'Wissen, was man tut Ethische Perspektiven auf Fragen ziviler Sicherheit und auf die Sicherheitsforschung in Deutschland', Zivilklauseln für Forschung, edited by Nielebock et al., pp. 255-269, at p. 261.

29 T. Nielebock, 'Ethische Herausforderungen friedenswissenschaftlicher Politikberatung', Handbuch Friedensethik, edited by I. Werkner and K. Ebeling (Wiesbaden: Springer VS, 2017), pp. 927-940, at p. 929. 30 See Nielebock, 'Ethische Herausforderungen', pp. 929-930.
To comply with a Civil Clause turns out to be a multilayered development which unites the need for discussion, empirical knowledge and teaching processes. ${ }^{31}$ This implies constant reflection on new experiences and the adjustment of guidelines.

At the same time, awareness-raising means (e.g. for dual-use-issues) have to be provided for university teaching processes as well as for the distinction of the terms peaceable/belligerent and civil/ military among students as well as university staff. Furthermore, the establishment of a monitoring body such as an ethical review committee can be useful for the implementation of the Civil Clause. The analysis and evaluation of cases is a necessity with regard to the complex delineation of military vs. civil use. Ethical review committees can function as counterparts who provide advice. The University of Passau has passed a resolution for the establishment of a commission for the ethics of security-related research (KEF) in October 2016. Its field of functions is outlined as follows: "Amidst the conflicting priorities of academic freedom and research responsibility, the KEF provides assistance by consulting and evaluating ethical aspects of security-related cases as mentioned in §6 paragraph 1. What is more, it promotes awareness-raising measures for security-related issues at Passau University." 32

According to §6 paragraph 1, members of Passau University who require counselling while realizing a research project can call on the commission for issues concerning significant security-related risks to human dignity, human life, health, freedom, property, the environment, and peaceful coexistence. Such security-related risks become relevant in the context of research which produces knowledge, products, or technologies that might be misused by third parties. Upon request, the commission comments on and evaluates the tenability of the project and recommends possible modifications and requirements for risk minimization. During the next years empirical knowledge has to display if this concept and the associated process will work and will be utilized.

Consultation by an ethical review commission based on voluntariness cannot be interpreted as an encroachment on the basic right of academic freedom. ${ }^{33}$ In that respect, ethical review commissions - embodying the depicted, ethos of academic responsibility' - might serve as an appropriate form of institutionalization given "the expanded range of responsibility of academia for the direct consequences of its research"34.

In conclusion, it has to be taken into consideration that the efficiency of ethical review boards is limited. A concise code of procedure has to be implemented. The selection and eligibility of board-members must not to be influenced by certain interests, but should rather represent the university's diversity as its potential applications. ${ }^{35}$ The achieved consensus is to be reassessed in order to clarify the diverse content-related positions and to rule out a mere pragmatic and viable solution. ${ }^{36}$ With all the efforts

31 See Holzner and Firges, 'Forschung', pp. 106-107.

32 Universität Passau, Richtlinien für die Kommission für Ethik sicherheitsrelevanter Forschung an der Universität Passau, para. 2,1, online at https://www.uni-passau.de/fileadmin/dokumente/wissenschaft/ Allgemeines/161026 KEF_Richtlinien_final.pdf (accessed 2017-06-20).

33 See Hufen, 'Wissenschaft', p. 119.

34 Nielebock, 'Ethische Herausforderungen', p. 930.

35 See Wozu Experten? Ambivalenzen der Beziehung von Wissenschaft und Politik, edited by A. Bogner/H. Torgersen, Wiesbaden: VS-Verlag 2005.

36 See S. Zotti, Theologische Ethik in Ethikkommissionen. Politikberatende Ethikkommissionen als Bewährungsfeld theologischer Ethik, Marburg: TectumVerlag, 2006, 218. 
undertaken, the common goal of working together must not be neglected: the question of responsibility of all involved persons is the ultimate criterion in the evaluation-process.

\subsection{The Civil Clause as a Means to Self-Assurance}

From an ethical point of view, the question concerning whether the Civil Clause can be rather understood as a kind of aim, a kind of self-assurance in professional ethics, or an internal obligation has to be considered. The Civil Clause should not merely or always at first be understood as an interdiction to military research, but also, in a better way, as a helpful requirement for developing research. There is a demand for watchfulness and attentiveness; the Civil Clause can mean insistence on reflection concerning the political and social consequences of every kind of research and possible issues of justice. That is why the Civil Clause should rather be understood as a means of self-assurance of universities. What are the aims, what are the purposes of research and lecturing? What are the values a university is standing for? The Civil Clause should be seen as a means to self-assurance for fundamental directions of universities.

\section{Summary}

By means of the Civil Clause, a university is able to take up responsibility for the pursuit of peaceful purposes voluntarily and to fulfill a certain normative stance toward the societal and political sphere. It can take up a greater portion of responsibility by the universities in a field of action, in this case for peace. But as we also tried to demonstrate, the Civil Clause as an instrument in university policy raises numerous questions that cannot be met by precise answers and which, therefore, generate persistent tensions.

In conclusion, an answer to the following question needs to be given: Which concrete purpose does this Civil Clause have? It can be said that the direct purpose of the Civil Clause is to reflect aims in research, lecturing and studies. The Civil Clause can be, especially in the legal perspective, only an instrument of self-assurance, a kind of self-obligation and responsibility to evaluate third-party funds, the purposes and interpretative categories in research, lecturing and studies, not a legal means. What is ultimately at stake is the role of universities in a democratic society. ${ }^{37}$

The Civil Clause, whose interpretation can be very difficult and controversial, can have a symbolic dimension to reflect (one's own) purposes of research and lecturing, but it should also be viable for practical implementation. In this regard an interdisciplinary constituted ethics-commission ${ }^{38}$ would be advisable in our opinion, as it is able to review individual requests and research applications.

37 See G. Stuby, 'Viel Lärm um die Zivilklausel', Das Recht in guter Verfassung? Festschrift für Martin Kutscha, edited by F. Roggan and D. Busch (BadenBaden: Nomos, 2013) pp. 219-229, at p. 221.

38 See 'Ethikrat statt Zivilklausel - An der Uni Kiel soll eine Ethikkommission Forscher und Studierende beraten, wenn sie bei den Konsequenzen ihrer Arbeit unsicher sind.' DUZ Magazine. Das Unabhängige Hochschulmagazin 69:9 (2013), p. 20.
As a consequence, some benchmarks for an acceptable Civil Clause, if favored by the majority of a university or faculty, would (at least) include the necessity of a multifaceted ethos safeguarding the Civil Clause, the demand for transparency throughout the process, and the need for terminological distinctions have to be stressed over and over again. Based on the German debate, the goal of this article was to raise awareness of these issues and to take baby steps towards finding answers.
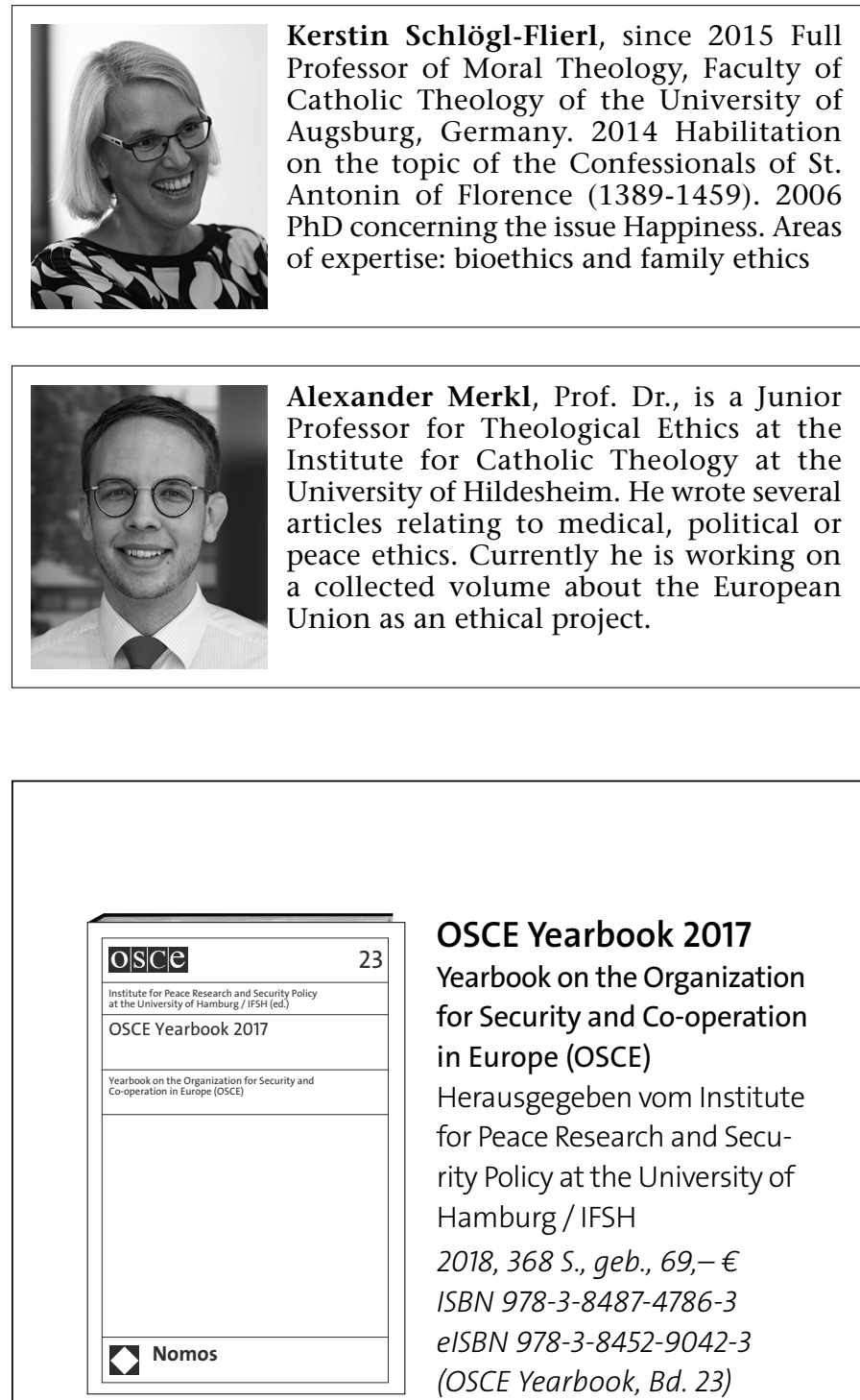

OSCE Yearbook 2017

Yearbook on the Organization for Security and Co-operation in Europe (OSCE)

Herausgegeben vom Institute for Peace Research and Security Policy at the University of Hamburg / IFSH

2018, 368 S., geb., 69,- $€$

ISBN 978-3-8487-4786-3

eISBN 978-3-8452-9042-3

(OSCE Yearbook, Bd. 23)

nomos-shop.de/36181

The responsibilities and activities of the Organization for Security and Cooperation in Europe: from conflict prevention and crisis management via the promotion of democracy and human rights to arms control - analysis and reports on its political and diplomatic practice.

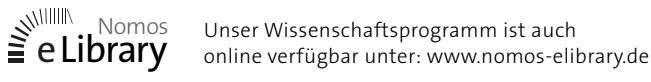

Portofreie Buch-Bestellungen unter www.nomos-shop.de Preis inkl. Mehrwertsteuer 